\title{
The stability evaluations of municipal landfill in Malaysia for future land use
}

\begin{abstract}
The research is about the investigation of the effects of landfill stability with relation to the solid waste composition in landfill site located in Selangor, Malaysia. The stability of a landfill relies on the shear strength of its elements and their settlement behaviour. Most of the landfill is made up of Municipal Solid Waste (MSW), so the overall stability of the landfill slopes is governed by the physical, chemical and mechanical properties of the MSW. The main objective of this research is to determine the relationship between solid waste composition and their mechanical properties in order to analyse the site stability. The workplan begin with the desk study and proceed with physical and chemical properties test followed by the implementation of details laboratory works for testing the mechanicals parameters. A landfill site has been selected and four samples location differred by age were chosen in order to have a clear view of the overall solid waste composition and the geotechnical condition of selected landfill site. Basic physical and chemical properties of MSW were carried out such as moisture content, specific gravity and organic content. In terms of mechanical properties; shear strength and settlement behaviour were investigated. At the end of this study, several salient points have been concluded with respected to the solid waste composition and the site stability analysis.
\end{abstract}

Keyword: Properties; Settlement; Shear strength; Site stability; Solid waste 